\title{
Environmentální bezpečnost: staronové téma všeobecného vzdělávání?
}

Svatava Janoušková, Tomáš Kudrna, Jan Maršák, Václav Pumpr

Envigogika 2013/VIII/1- Recenzované články/ Reviewed Papers

Publikováno/Published 31 05. 2013

DOI: http://dx.doi.org/10.14712/18023061.228

\begin{abstract}
Abstrakt
Článek se zabývá environmentální bezpečností z hlediska vzdělávání - konceptem, který stojí $v$ současnosti $v$ ohnisku zájmu odborné i laické veřejnosti, ale který u nás doposud nebyl z pohledu vzdělávání zpracován. Text se věnuje jednak provázanosti obecného konceptu environmentální bezpečnosti se vzdělávacím obsahem vyučovacích předmětů resp. vzdělávacích oborů v kurikulech nižšího sekundárního vzdělávání od roku 1948 po současnost, a jednak otázce, jak by tato tématika měla být zohledněna $v$ současném kurikulu.
\end{abstract}

\section{Klíčová slova}

environmentální bezpečnost, historie environmentální bezpečnosti v kurikulech (1948- 2012)

\begin{abstract}
The concept of environmental security stands in the focus of professionals as well as the lay public nowadays; however, a comprehensive analysis of this concept in the Czech curricula on the lower secondary level has been missing up to now. The authors seek to bring the first insight in this issue in the article. The text deals with the general environmental security concept (a component of a human security concept) and analyzes the interconnections among the general environmental security concept topics and educational content in Czech curricula of the lower secondary education in a particular time period (1948 - present). At the end the authors propose possible changes in the current curricula and point out the importance to develop new appropriate educational tools for a broader use in schools.
\end{abstract}

\section{Key words} (1948-2012)

environmental security, history of environmental security issues in the curricula 


\section{Úvod}

Pojem bezpečnosti není ve vzdělávacích standardech ${ }^{1}$ všeobecného vzdělávání v českých zemích pojmem novým. Zmíněný pojem sice nabývá v rozličných obdobích různých významů a je provázán, podle typu aktuálního faktického nebo očekávaného ohrožení společnosti, s různým typem vzdělávacího obsahu, vždy je ale v nějaké formě ve standardech prítomen a to jak ve společenskovědních, tak v přírodovědně-technologických oborech. Navíc se pojmy spojené s pojmem bezpečnosti, např. obrana, vyskytují rovněž přímo ve školských zákonech. Například v úvodním ustanovení Zákona o školské soustavě a vzdělávání učitelư z roku 1953 (zákon č. 31/1953 Sb.) je explicitně uvedeno, že škola je spjata s hospodářsko-technickým a kulturním rozvojem vlasti, ale také s její obranou. Školský zákon č.186/1960 Sb. zase zmiňuje brannou výchovu jako nezbytnou složku základního vzdělávání. Branná výchova se pak jako součást vzdělávání na školách udržuje velmi dlouhou dobu, až do počátku 90. let, ačkoli je třeba ji vnímat spíše jako jakési doplňkové téma vzdělávání realizované ( $v$ dnešní terminologii) zpravidla formou celodenního projektu.

Fenomén branné výchovy je u generace lidí, kteří jí prošli v sedmdesátých a osmdesátých letech, vnímán často jako humorná vzpomínka. Mnozí z nás si ještě vybavují, jak s plynovými maskami, jejichž velikost byla pečlivě zaznamenávána na počátku školního roku, organizovaně sbíhají, po výzvě v rozhlase, nebo i po signálu sirény, v pláštěnkách a s igelitovými sáčky na rukou i na nohou do sklepa školy. Tam školník pečlivě označenými cihlami zastavoval vchod. Nicméně takto proškolení lidé věděli, kam běžet, když by se ozvaly údery na kolejnici. Věděli co jíst a nejíst při radioaktivním útoku, jak zacházet s maskou při požáru, pokud měla uhlíkový filtr, a jak postupovat při jejím nasazování. Necháme-li stranou ideologický aspekt této činnosti, a fakt, že muselo být na geopolitické mapě znázorněno, odkud hrozí největší nebezpečí útoku, musíme konstatovat, že branná výchova a branná cvičení nebyla ničím škodlivým.

A je také nesporným faktem, že branná výchova byla realizována již ve školách za první republiky, protože bezprostředně po první světové válce byla vnímána jako důležitá součást vzdělávání v případě dalšího možného ohrožení země, a její význam se potom samozřejmě akcentoval v druhé polovině třicátých let 20 . století, kdy byla válečná hrozba již hmatatelná.

V současnosti je branná výchova minulostí ${ }^{2}$ a také problematika obrany státu je ve výuce prozatím spíše okrajovou záležitostí. Hrozby přesto stále existují. Možná ne vojenské či válečné, $v$ našich podmínkách pravděpodobně nehrozí ani teroristické útoky $v$ takové míře, aby bylo nutné jim věnovat zvýšenou pozornost tím, že budeme připravovat žáky na jejich možný dopad a nacvičovat možné způsoby, jak se při nich chovat. Co ovšem nabývá na aktuálnosti, jsou různé typy přírodních hrozeb - povodně, hurikány, extrémní výkyvy počasí - např. tropické teploty a s nimi spojené doprovodné jevy, hrozby plynoucí z kontaminace prostředí chemickými látkami (včetně radioaktivních) způsobené jejich výrobou nebo manipulací $s$ nimi, různé typy technologických i lidských selhání $v$ průmyslových podnicích s následky na lidském zdraví a majetku, nebo možnost nových epidemií chorob. Aktuální jsou ovšem rovněž témata sociální, jako např́klad způsoby chování ve vyostřených občanských sporech, vnímání sociálních rozdílů ve společnosti nebo role občana $v$ ní.

1 Vzdělávacím standardem máme na mysli obecně učební plány, učební osnovy, vzdělávací standardy i rámcové vzdělávací programy.

${ }^{2}$ Podotýkáme ovšem, že na některých českých školách se s určitou jejich formou můžeme setkat doposud. 
Všechny tyto uvedené hrozby se dají shrnout pod pojem, kterým se u nás ve vzdělávání doposud neoperuje, ale který je v současnosti ve středu zájmu environmentalistů. Je to pojem environmentální bezpečnost.

V našem článku, který je analytickou studií zařazení problematiky environmentální bezpečnosti do základního vzdělávání - nižšího sekundárního vzdělávání (odpovídajícího 6. - 9. ročníku ZŠ nebo 1. - 4. ročníku osmiletého gymnázia), přinášíme informace o tom, jak je obvykle pojem environmentální bezpečnosti definován, a jaký přístup je $v$ současnosti k problematice environmentální bezpečnosti uplatňován v České republice. Dále se zabýváme tím, jak je problematika environmentální bezpečnosti vyjádřena v Rámcovém vzdělávacím programu pro základní vzdělávání ( $v$ jeho revidované verzi) a kde vidíme potenciál pro její uplatnění ve výuce. Článek reflektuje rovněž témata environmentální bezpečnosti v dřívějších dokumentech - kurikulech ${ }^{3}$ datovaných od druhé světové války, konkrétně od roku 1948 do současnosti, a to zejména v oblasti prírodovědnětechnologických oborů (a případně branné výchovy v těch učebních osnovách a standardech, kde je tento druh výchovy zmiňován). Rozsah článku přirozeně neumožňuje jmenovat všechna konkrétní témata jednotlivě. Jeho snahou je spíše ukázat provázanost tehdejšího pojetí environmentální bezpečnosti s př́klady ze vzdělávacího obsahu jednotlivých vyučovacích předmětů, resp. vzdělávacích oborù.

V článku vycházíme z pojetí rámce environmentální bezpečnosti, který je součástí projektu Integrované hodnocení dopadư globálních změn na environmentální bezpečnost České republiky (EnviSec). Schéma rámce, z nějž vycházíme, přinášíme na obr. č. $1^{4}$. Tento rámec představuje $v$ současnosti nejnovější pohled na problematiku environmentální bezpečnosti zohledňující nejmodernější poznatky, které jsou dostupné v české a zejména zahraniční odborné literatuře. Schematizace problematiky environmentální bezpečnosti umožňuje rychlou orientaci v základních poznatcích týkajících se daného tématu a umožňuje tak relativně rychlou orientaci $v$ dané problematice.

\title{
Provázanost témat environmentální bezpečnosti a vzdělávacích témat přírodovědných oborů českých kurikul v historickém kontextu.
}

\author{
Environmentální bezpečnost v 70. letech 20. století
}

Pojem environmentální bezpečnosti je pojmem relativně novým. Termín environmental security se objevuje v bezpečnostních studiích od počátku 70. let 20. století. V roce 1972 totiž vychází důležitá studie Meadowse a kol. (1972) přinášející matematický model, který poukázal mj. na fakt, že množství obnovitelných zdrojủ je konečné, a navíc, že nedostatek některých strategických zdrojů při tehdejším trendu spotřeby může nastat již v počátku 21. století. Zájem o tuto studii a o problematiku surovin obecně pak vrcholil $v$ roce 1973, kdy došlo k tzv. ropné krizi. Jak uvádí ve své studii z roku 1995 Dabelko a Dabelko, tato událost posunula tradiční pojetí bezpečnosti do naprosto jiné roviny. Ukázalo se, že ohrožení státu nemusí nastat jen z důvodu přímého ozbrojeného konfliktu, ale stát může být také ohrožen nedostatkem klíčových surovin, který by výrazně omezil jeho ekonomický růst. Ropná krize byla skutečně závažným tématem, nebot' řada do té doby značně prosperujících zemí (např. Spolková republika Německo) upadla do ekonomické recese provázané rủstem

\footnotetext{
${ }^{3} \mathrm{~V}$ textu jsou uváděny pedagogické odborné termíny (např. učební osnovy, vyučovací předměty atp.) pro konkrétní období vždy tak, jak byly platné a užívané v daném období v citovaných pedagogických dokumentech.

${ }^{4}$ Schéma přinášíme pro přehlednost a snadnou orientaci čtenáře pouze do úrovně dílčích komponent environmentální bezpečnosti.
} 
nezaměstnanosti. Suroviny a jejich dostatek se staly také tématem tehdejšího socialistického bloku zemí. Tyto země, zejména díky Svazu sovětských socialistických republik, ropnou krizí postiženy nebyly, ale začaly si naplno uvědomovat potencionální sílu/slabinu, kterou dostatek/nedostatek klíčových surovin může sehrát ve studené válce. Environmentální bezpečnost je tedy $v$ té době interpretována zejména jako bezpečnost surovinová a energetická, a další témata, která v současnosti pod pojem environmentální bezpečnosti řadíme (např. potravinová bezpečnost), byla součástí tradičních bezpečnostních studií.

V českých učebních osnovách se problematika surovinové bezpečnosti v nižším sekundárním vzdělávání začíná objevovat v druhé polovině sedmdesátých let. Neznamená to ale, že by se ve výuce problematice surovin nevěnovala pozornost již před tím. Do určité míry nacházíme témata, jakými jsou např. zpracování kovů nebo šetření surovinami, již v osnovách z padesátých a šedesátých let (viz Učební osnovy pro 6-11. postupný ročník všeobecně vzdělávacích škol, 1954, Učební osnovy základní devítileté školy, 1960), nicméně zvýšený zájem o dané téma se projevuje zejména v učebních osnovách od roku 1978, kdy se např. výuka prírodovědných předmětů - chemie a přírodopisu více začala zabývat problematikou těžby surovin, využíváním nerostných surovin člověkem nebo významem ropy, zemního plynu a uhlí v chemické výrobě a výrobách dalších (viz citace osnov v literatuře).

Ve středu zájmu výuky přírodovědných předmětů v sedmdesátých letech rovněž stojí problematika potravinové bezpečnosti. Ta se dotýká dvou hlavních okruhů zájmu. První je kontaminace potravin znečištujúcími komponentami chemické nebo biologické povahy, přičemž uvažuje kontaminaci záměrnou i nezáměrnou. Zmiňovaná problematika je vyučována nejen v rámci přírodovědných předmětů, ale rovněž v samostatném předmětu branná výchova. Druhým okruhem zájmu je výnos a ochrana zemědělských plodin před škůdci. Potravinová bezpečnost však není v osnovách tématem novým, nebot' je přítomna i v osnovách z let padesátých a šedesátých. Potravinová bezpečnost totiž byla tradičně bezpečnostním tématem ve výuce bez ohledu na to, zda byl v odborné literatuře již pojem environmentální bezpečnosti zaveden. Za podobně tradiční bezpečnostní téma Ize považovat ochranu obyvatelstva před nebezpečnými chemickými látkami, látkami radioaktivními a biologickými zbraněmi. Ve výuce přírodopisu se také pozvolna začíná objevovat téma ochrany životního prostředí (Učební osnovy základní školy, 1978).

\section{Environmentální bezpečnost v 80. letech 20. století}

V osmdesátých letech se obecné pojetí environmentální bezpečnosti poněkud proměňuje. Do ohniska zájmu decisní sféry, odborné i laické veřejnosti se totiž po jiné linii dostává koncept udržitelného rozvoje, který mění do značné míry pohled člověka na suroviny energetické i neenergetické povahy a především mění jeho přístup k životnímu prostředí. Akcentuje také nutnost zachování prírodního bohatství pro budoucí generace. Světová komise o životním prostředí a rozvoji OSN vydává zprávu "Naše společná budoucnost", která tento závazek vưči budoucím generacím deklaruje (WCED, 1987). Autoři jako je Ullman (1983) nebo Mathews (1989) proto upozorňují na nutnost nové definice environmentální bezpečnosti, která by se měla orientovat nejen na suroviny a energetiku, ale do značné míry také na životní prostředí a více akcentovat to, co se nazývá ekologickou bezpečností.

Z hlediska osnov přírodovědných předmětů v nižším sekundárním vzdělávání je pozornost věnována stejně jako $v$ letech sedmdesátých a osmdesátých surovinové a energetické bezpečnosti, tedy výrobě kovů, zpracování ropy, zemního plynu, uhlí a jejich využití v průmyslu a energetice. Oproti osnovám ze sedmdesátých let je ale daleko více prosazován koncept ochrany životního prostředí jakožto nutné podmínky pro existenci člověka a kvalitu jeho života. Problematika je zohledněna ve výuce chemie, občanské nauky, př́rodopisu i fyziky. Výuka chemie se $v$ té době zaměřovala na problematiku znečištování vod a ovzduší, a to zejména s ohledem na lidské zdraví. Žáci v rámci výuky rovněž získávali informace o vlivu některých chemických látek zejména organických na životní prostředí, 
a potencionálním vlivu na zdraví člověka. Řešena byla například otázka nebezpečnosti DDT či polychlorovaných bifenylů.

Ve výuce stále ještě byla vyučována témata týkající se otázek bezpečnosti jaderné energie i s důrazem na hrozbu ohrožení jadernými zbraněmi, a součástí výuky chemie byla rovněž témata jako využití chemických látek ve vojenství a způsob ochrany před těmito látkami. $\vee$ rámci výuky zeměpisu resp. př́rodopisu byla také diskutována potravinová bezpečnost, a to ve dvou rovinách - z hlediska dostupnosti potravin a jejich kvality (viz Učební osnovy základní školy, 1987).

Pro zajímavost Ize také uvést, že v sedmdesátých a osmdesátých letech tehdejší celostátně platné jednotné učebnice všech předmětů musely obsahovat centrálně předepsané složky „branné výchovy". Za tímto účelem bylo zřízeno na Výzkumném ústavu pedagogickém $v$ Praze oddělení, které sledovalo, zda jsou konkrétní předepsané složky $v$ rukopisech jednotných učebnic př́tomny. Ve výuce chemie byly takovými složkami např. témata související s požáry a jejich hašením nebo používání ochranných pomưcek při chemickém, či radiačním nebezpečí apod.

\section{Environmentální bezpečnost v 90. letech 20. století}

Po pádu „železné opony" na počátku 90 . let dochází k všeobecné proměně situace $\checkmark$ oblasti environmentální bezpečnosti. Bezpečnostní strategie přirozeně nemohou opomíjet problematiku surovinové nebo energetické bezpečnosti, ale postupně se do nich stále více promítá také problematika ekologické bezpečnosti (někteří autoři, např. Allenby (2000) nazývají tento druh bezpečnosti bezpečností biologickou). Mathews (1989) rozvíjí koncept, který se dotýká problematiky bezpečnosti dodávek obnovitelných zdrojů - vody, potravin, ale prosazují se i další témata jako např́ílad problematika systematického zajištování humanitární pomoci pro odstranění chudoby. Také významné mezinárodní organizace, např. Program OSN pro rozvoj (UNDP), přichází s novým vymezením pojetí lidské bezpečnosti, přičemž environmentální bezpečnost je jednou ze sedmi hlavních komponent $v$ tomto pojetí. Podle Paris (2001) je koncept environmentální bezpečnosti zohledňován v řadě studií zabývajících se lidskou bezpečností jako celkem.

$\checkmark$ devadesátých letech dochází $\mathrm{k}$ velké proměně $\mathrm{v}$ českém školství. Vzniká nový kurikulární dokument - Standard základního vzdělávání (1995) -, který byl oproti předchozím platným osnovám výrazně liberálnější jak z hlediska striktnosti stanovení vzdělávacího obsahu, tak z hlediska naplňování obsahu v konkrétních ročnících (škola může konkrétní výstupy Standardu základního vzdělávání naplňovat např. v rozmezí dvou let). A také obsah učiva s ohledem na problematiku bezpečnosti se významně proměňuje. Dosti obecně pojatý Standard základního vzdělávání pak doprovázely tři vzdělávací programy: Základní škola, Obecná škola a Občanská škola, které jej v různých aspektech upřesňovaly. Většina škol využívala program Základní škola (1996).

V rámci vzdělávacího programu Základní škola Ize pozorovat významný posun vzdělávacího obsahu, ve kterém se výrazně proměňuje vnímání role člověka v okolním prostředí a kvality jeho života. Problematika životního prostředí je silně akcentována v prírodovědných předmětech na druhém stupni - chemii, př́rodopisu, fyzice, v prrírodovědně společensko-vědním předmětu - zeměpisu i v předmětech společenskovědních - hlavně v občanské výchově a výchově ke zdraví. Environmentálně bezpečnostní témata již postrádají vzdělávací obsah související s dřívějším rozdělením světa na země na jedné straně v socialistickém bloku a na druhé straně na země kapitalistické a z toho plynoucí hospodářsko-politické konsekvence, i když hospodářské a politické uspořádání jednotlivých zemí je $v$ rámci výuky stále uváděno. $V$ oblasti surovinové a energetické bezpečnosti se vzdělávací obsah výrazně zaměřuje na problematiku (vy)čerpání zdrojů (občanská nauka, zeměpis), ve výuce chemie je potom věnována pozornost problematice efektivních metod využívání primárních zdrojů pro výrobu prvků či sloučenin, ale také způsobech znovuvyužití a recyklaci surovin. Fyzika se tradičně zabývá problematikou výroby energie a jejím přenosem, pozornost je přirozeně věnována rovněž jaderné energetice. Z oblasti ekologické bezpečnosti je věnována pozornost kvalitě lidského života s ohledem na čistotu prostředí, 
v němž člověk žije (problematika kvality vody i ovzduší), pozornost je rovněž věnována kvalitě stravování s ohledem na rozvoj různých typů onemocnění (předmět rodinná výchova). Péčí o zdraví (např. prevence onemocnění, ochrana před nákazou, toxické látky v potravním řetězci) se zabývá rovněž přirodopis a rodinná výchova a výchova ke zdraví. Problematika ochrany ekosystémů je potom obsahem přírodopisu, zeměpisu a do určité míry i občanské nauky. Je však nutné konstatovat, že s výjimkou první pomoci získávají žáci spíše teoretické poznatky o př́činách vzniku environmentálně-bezpečnostních problémů, spíše než aby u nich byly rozvíjeny dovednosti správného chování při mimořádných událostech.

\section{Environmentální bezpečnost na počátku 21. století}

Se sílícími projevy výkyvů počasí (vichřice, záplavy, extrémní sucha), s opakovanými problémy s přemnožením nepưvodních organismů $v$ daném prostředí a se stále obtížnější schopností prrírodního prostředí vyrovnat se s následky lidské činnosti dochází celosvětově k navýšení počtu mimořádných událostí, jimž lidská společnost musí čelit. Zájem o problematiku environmentální bezpečnosti tak sílí. Dokladem je jednak nárůst počtu publikací zabývajících se daným tématem, jednak narůstající počet projektů, které jednotlivá environmentálně bezpečnostní témata řeší. Pozornost je rovnoměrně rozmístěna mezi všechny hlavní komponenty bezpečnosti - surovinovou, energetickou i ekologickou. Velká pozornost je věnována zejména problematice globální změny klimatu, ale také surovinové či energetické bezpečnosti z důvodu nerovnoměrného rozložení strategických surovin (např. kovů vzácných zemin, ropy, zemního plynu, grafitu) mezi jednotlivými zeměmi světa.

Rámcový vzdělávací program pro základní vzdělávání (VUP, 2007) v zásadě potřeby problematiky environmentální bezpečnosti z hlediska témat pokrýval, přičemž $v$ základních aspektech a parametrech korespondoval se zpracováním environmentálně bezpečnostních témat ve stejných vzdělávacích oborech, jako Standard základního vzdělávání resp. vzdělávací program Základní škola $v$ jeho jednotlivých předmětech (1996). Více akcentována je však opět složka poznání př́čin vzniku environmentálně bezpečnostního problému, spíše než chování se při něm, podobně jako je tomu v předchozím případě - u vzdělávacího programu Základní škola. V roce 2012 proběhla pravidelná revize kurikula. Při této revizi (platná od 1.9. 2013) došlo k doplnění vzdělávacího obsahu souvisejícího s problematikou environmentální bezpečnosti přítomném v Rámcovém vzdělávacím programu pro základní vzdělávání z roku 2007. Jaké jsou tyto změny? V prvním vzdělávacím období je problematika chování za mimořádných událostí zohledněna zejména ve vzdělávací oblasti Člověk a jeho svět. Žáci mají být schopni po dokončení primárního vzdělávání rozpoznat situaci ohrožující jejich zdraví a život, aplikovat správný způsob chování v těchto situacích, a pomoci druhým v případě, že je jejich pomoci potřeba (např. přivoláním pomoci). Pozornost se $v$ tomto období má zaměřit: na rozpoznání varovných signálů, pochopení funkce integrovaného záchranného systému, pochopení vzniku přírodních mimořádných událostí i událostí zejména antropogenního původu (např. vznik požárů). I když tedy riziko povodní či mimořádných výskytů sucha či vichřic nejsou na rozdíl od požárů explicitně zmíněny, implicitně jsou zahrnuty ve výstupu: stručně charakterizuje specifické prírodní jevy a z nich vyplývající rizika vzniku mimořádných událostí, v modelové situaci prokáže schopnost se účinně chránit.

Z našeho pohledu by bylo vhodné ještě mírně rozšířit problematiku potravinové bezpečnosti (s ohledem na kvalitu konzumovaných potravin i plýtvání jimi). Kvalita konzumovaných potravin je nyní v ohnisku zájmu veřejnosti, nebot' na náš trh proniká řada i zdravotně problémových až závadných potravin. Žáci také často s rodiči cestuji a měli by být informováni o odlišné kvalitě potravin i pitné vody v cizích zemích. Toto drobné navýšení vzdělávacího obsahu může být reflektováno v tematickém okruhu Člověk a jeho zdraví.

Považujeme za důležité rovněž zohlednit do té míry, jaké jsou žáci této věkové skupiny dané problematiku vnímat, také témata energetické a surovinové bezpečnosti, zejména pak závislosti lidské společnosti na zdrojích surovin. Domníváme se, že výstup s tímto námětem by mohl být nově integrován do tematického okruhu rozmanitost př́rody, nebo mírně rozšiřit stávající výstupy týkající se problematiky využívání neživé přírody člověkem 
v tomto tematickém okruhu. Je velmi žádoucí, aby si žáci byli vědomi toho, jak získávání zdrojů poškozuje prostředí, ale také toho, že bez prírodních zdrojů nejsme už schopni existence $v$ současném pojetí života a že bez přístupu k těmto zdrojům je lidská společnost velmi zranitelná.

Také v nižším sekundárním vzdělávání se projevuje navýšení vzdělávacího obsahu o témata environmentální bezpečnosti. Chování při mimořádných událostech, ale také principy kolektivní ochrany jsou zohledněny ve vzdělávací oblasti člověk a společnost. Vzdělávací oblast člověk a príroda již před revizí RVP ZV řadu témat environmentální bezpečnosti reflektovala, nicméně nikoli v optimální míre. Doplněna byla o problematiku rozpoznání a odpovídající způsoby chování při mimořádných událostech přírodního původu (povodně, vichřice, sněhové kalamity apod.) ve vzdělávacím oboru př́rodopis. Obdobně byl upraven jeden z výstupů vzdělávacího oboru zeměpis. Podobně jako v předchozím případě však postrádáme větší akcent na potravinovou, surovinovou a energetickou bezpečnost. Domníváme se, že poslední dva zmíněné typy bezpečností by se měly promítnout zejména do výuky zeměpisu. Implicitně jsou přirozeně zmíněny v řadě výstupů, bylo by však zapotřebí více zdưraznit at' už ve výstupech nebo v učivu příslušných tematických okruhů problematiku:

- závislosti hospodářství země na surovinách a potencionální závislost zemí, zejména ČR na dovozu klíčových surovin a kvalitě infrastruktury dodávek klíčových surovin (mírné rozšiření stávajícího výstupu o energetických a surovinových zdrojích v tematickém okruhu Společenské a hospodářské prostředí)

- $\quad$ nerovnoměrného rozmístění surovin vč. vody na Zemi a možnost rozvoje konfliktu (místního, mezinárodního) o zdroje (mírné rozšíření výstupu tematického okruhu Regiony světa týkající se potencionálních změn jednotlivých světových regionů event. mírné rozšiření výstupu tematického okruhu společenské a hospodářské prostředí týkající se geopolitických a politických změn v konkrétních regionech světa.)

- $\quad$ prístup k potravinám z hlediska množství, kvality a sociálního postavení z hlediska různých - chudých a bohatých - regionů světa (mírné rozšíření tematického okruhu společenské a hospodářské prostředí rozšířené o samostatný výstup týkající se specificky zemědělství, případně v rámci učiva specifikovat potravinovou bezpečnost jako jedno $z$ důležitých témat)

Další příležitostí, jak více zohlednit environmentální bezpečnost ve smyslu kvality přijímaných potravin, by mohla být vzdělávací oblast výchova ke zdraví. Podobně, jako bylo navrženo pro vzdělávací oblast člověk a jeho svět, by měla být diskutována kvalita potravin z hlediska př́tomnosti biologické či chemické kontaminace. S ohledem na znalosti žáků by mohly být dobře využity znalosti z prrírodopisu resp. chemie pro hlubší proniknutí do dané problematiky.

V současné době platí, že vysoká autonomie škol díky možnosti vytváření vlastního kurikula - Školního vzdělávacího programu (vycházejícího ovšem z RVP ZV) - umožňuje školám uchopit dané téma podle svých pedagogických záměrů a kromě teoretických poznatkư školy také mohou žákủm poskytovat praktické dovednosti, at' už formou k tomu vytvořených úloh, či formou základního praktického nácviku v projektových dnech. To vytváři velký potenciál v možnosti smysluplné výuky nejdůležitějších témat environmentální bezpečnosti, témat, která se jeví v současnosti jako nejvýše aktuální. Jsou to dle našeho názoru témata ekologické bezpečnosti - zejména rozpoznávání a nácviku správného jednání při mimořádných událostech přírodního i antropogenního původu. Dále problematika potravinové bezpečnosti z hlediska kvality a kvantity potravin a jejich nerovnoměrného rozdělení $v$ jednotlivých regionech světa. Opomíjená by neměla přirozeně být ani problematika energetické a surovinové bezpečnosti - konkrétně přístupu ke klíčovým surovinám energetického a neenergetického původu. Surovinám, bez nichž není možný rozvoj hospodářství jednotlivých regionů světa. Podklad pro náš lobbing za daná témata má oporu jednak $v$ bezpečnostních strategiích ČR, jednak $v$ bezpečnostních strategiích dalších 
evropských zemí (Německa, Polska, Slovenska, Nizozemí ad.), kde se tyto okruhy problémů velmi zásadně diskutují. Fakt, že se nejedná o problémy marginální, dokazuje také narưstající počet článků v odborném i běžném tisku. Hospodářské noviny např. věnují průběžně značnou pozornost problematice energetické a surovinové bezpečnosti a to nejen v návaznosti na takové události jako byla "válka o plyn" mezi Ruskem a Ukrajinou v roce 2009, nebo snížení dodávek kovů vzácných zemin na světové trhy Čínou, aby upozornili na zranitelnost ekonomik zemí světa i České republiky. Rovněž potravinová soběstačnost, dovoz a výroba nekvalitních potravin jsou velmi častým námětem reportáží veřejných médií. A oprávněně, nebot́ kvalita potravin výrazně ovlivňuje zdraví občanů.

Témata environmentální bezpečnosti jsou v aktuálně platném kurikulu (MŠMT ČR, 2013) do větší či menší míry př́tomna, jak jsme prokázali výše. Domníváme se, že k drobným úpravám, které by však významně nenavýšily vzdělávací obsah, spíše by současnou výuku směřovaly mírně odlišným směrem, by v kurikulu mělo stále ještě dojít. Jedná se o návrh, který by měl být detailně diskutován při dalších revizích kurikula skupinou odborníků na danou problematiku.

\section{Závěr}

Vzdělávání je jednou ze základních podmínek nutnou pro realizaci bezpečnostních strategií, které státy vyvíjejí za účelem ochrany obyvatelstva ${ }^{5}$. Jak deklaruje řada národních bezpečnostních strategií, jedná se nejen o vzdělávání armády příslušné země či záchranných složek země (např. hasiči, policie či zdravotníci), ale také o vzdělávání obyvatelstva, které může, díky svému správnému chování v případě ohrožení, činnosti těchto složek napomoci. Analýza minulých školních osnov i kurikula současného tak umožnila prokázat, jak je u nás vzdělávána populace žáků v nižším sekundárním vzdělávání právě v této problematice a jak je vzdělávání provázáno $s \mathrm{v}$ dané době aktuálními environmentálně-bezpečnostními problémy.

Jak jsme analýzou minulých školních osnovi kurikula současného prokázali, environmentálně bezpečnostní témata jsou tradiční součástí formálních kurikul. Smyslem těchto témat vždy bylo vybavit žáky takovými vědomostmi, dovednostmi a postoji (kompetencemi), které se $v$ dané době zdály pro praktický pracovní i osobní život nejdůležitějšími, někdy nezbytnými. Tato nutnost je deklarována v analyzovaných kurikulech a je akcentována rovněž $v$ nejaktuálnější verzi Rámcového vzdělávacího programu pro základní vzdělávání v charakteristikách vybraných vzdělávacích oblastí (člověk a jeho svět, člověk a společnost, člověk a přiroda, člověk a zdraví), stejně jako je do určité míry zohledněna $v$ celkovém zaměření vzdělávání. Žáci $v$ nižším sekundárním vzdělávání vždy byli vzděláváni v problematice zacházení s chemickými látkami, poskytování první pomoci, jednání $v$ případě požárů či havárií. Učili se chápat závislost člověka na energetických a neenergetických surovinách i vnímat rozmístění zásob takových surovin v jednotlivých zemích světa $v$ souvislosti $s$ jejich politickým uspořádáním (zejména ve výuce zeměpisu). $\checkmark$ průběhu několika dekád narưstal rovněž počet témat, která se týkala vlivu člověka na prostředí a s tím spojených bezpečnostních rizik. Ve středu zájmu se tak například ocitl koncept udržitelného rozvoje, který propojoval problematiku environmentální s problematikou sociální (včetně ekonomické). Do ohniska stále většího zájmu se v současné době rovněž dostávala problematika osobního bezpečí v rámci výuky výchovy $k$ občanství, problematika zdraví s ohledem na šírení nových druhů onemocnění (přírodopis, výchova ke

\footnotetext{
${ }^{5}$ Environmentální bezpečnost je v řadě strategií včetně ČR explicitně zmíněna jako jedna z neopominutelných složek každé takové strategie.
} 
zdraví) nebo problematika potravinové bezpečnosti z hlediska prevence civilizačních chorob či obsahu zdraví škodlivých látek.

I když kurikula na aktuální témata reagovala s určitým zpožděním daným jejich revizemi, základní škála nejnutnějších témat environmentální bezpečnosti byla vždy reflektována (i když v některých případech byla doprovázena politickou propagandou dané doby). Také současné kurikulum reflektuje nejnutnější témata environmentální bezpečnosti, jak jsme prokázali výše. Domníváme se však, že některá shora uvedená témata, která jsou ted' přítomna v Rámcovém vzdělávacím programu pro základní vzdělávání spíše implicitně, by měla být více explicitně vyjádřena, aby tak například problematika energetické či surovinové bezpečnosti byla žákům dobře přiblížena - a to s ohledem na aktuální geopolitické uspořádání světa - a ilustrována na událostech historických i současných.

Revize kurikula je však jen prvním krokem na dlouhé trati. Od zamýšleného kurikula ke kurikulu realizovanému je dlouhá cesta a učitelům by měla být maximálně usnadněna. Proto je třeba rovněž apelovat na tvưrce didaktických materiálů, aby se v návaznosti na publikace z počátku 21. století (viz např. Beneš et al., 2006, Herink and Balek, 2002, Horská et al., 2002, Sedláček, 2006a,b) environmentálně bezpečnostní problematikou dále zabývali a to $s$ ohledem na nejaktuálnější trendy a témata daného konceptu. Žákům by měla být poskytnuta široká škála studijních opor, které by jim usnadnily pochopení konceptu environmentální bezpečnosti $v$ její maximální šíři. Učitelé by měli mít možnost se $v$ dané problematice dále vzdělávat, nebot' informace, které mají k dispozici, nejsou vždy neaktuálnější nebo jejich dohledání vyžaduje velké úsilí. Domníváme se, že před tvưrci didaktických materiálů stojí velký úkol - vytvořit didaktické materiály s tématy environmentální bezpečnosti a průběžně je aktualizovat. Environmentálně bezpečnostní témata se totiž s rychle se měnícím světem ve své naléhavosti mohou relativně rychle proměňovat. Zvláštní pozornost by se pak dle našeho názoru měla věnovat praktickému nácviku chování za mimořádných událostí. Pozornost by se měla upř́t zejména k praktickému nácviku chování za událostí přírodního původu, jakými jsou povodně. Žáci by mohli například cvičit dovednost rychle a správně sbalit evakuační zavazadlo či dbát bezprostředně simulovaných příkazů integrovaného záchranného systému otevírajícího možnost rychlé evakuace $v$ případě ohrožení života. Vhodná by k tomuto účelu mohla být např. projektová výuka.

Příspěvek si kladl za cíl přinést přehled o vývoji problematiky environmentální bezpečnosti $v$ historii i současnosti a přinést některé první informace o tom, jak danou problematiku ve výuce uchopit. Věříme, že článek mezi odbornou pedagogickou veřejností otevře diskuzi nad tím, jak danou problematiku na školách efektivně vyučovat, aby dle bezpečnostní strategie ČR lidé byli schopni do maximální možné míry chránit své životy, zdraví a majetek svŭj i dalších spoluobčanů.

\section{Poděkování:}

Článek vznikl v rámci řešení projektu „Integrované hodnocení dopadů globálních změn na environmentální bezpečnost České republiky“" (VG20122015091), kterýje financován z Programu bezpečnostního výzkumu ČR. 
Obr. 1

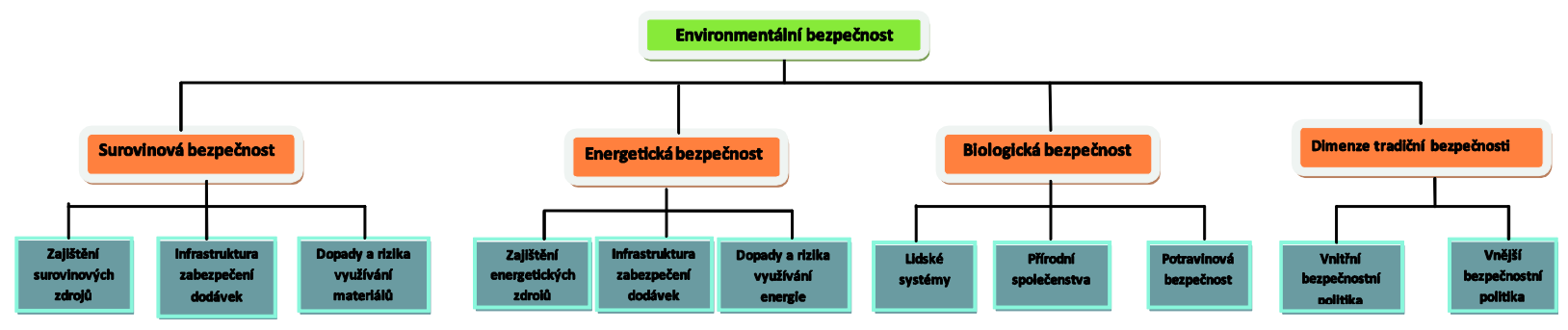




\section{Literatura}

- Allenby, B. R. (2000). Environmental Security: Concept and Implementation. International Political Science Review, 21(1), 15-21. Retrieved from http://ips.sagepub.com/cgi/doi/10.1177/0192512100211001 http://dx.doi.org/10.1177/0192512100211001

- Barnett, J. (2001). The meaning of environmental security: Ecological politics and policy in the new security era. London: Zed Books.

- Beneš, P., Pumpr, V., \& Čapoun, T. (2006). Ochrana člověka za mimořádných událostí - Havárie s únikem nebezpečných látek, Radiační havárie. Praha: Fortuna.

- Dabelko, G. D., \& Dabelko, D. D. (1995). Environmental Security: Issues of Conflict and redefinition. Woodrow Wilson Environmental Change and Security Project Report, 1(3), 3-12.

- Herink, J., \& Balek, V. (2002). Ochrana člověka za mimořádných událostí - Živelní pohromy. Praha: Fortuna.

- Horská, V., Marádová, E., \& Slávik, D. (2002). Ochrana člověka za mimořádných událostí - Sebeobrana a vzájemná pomoc. Praha: Fortuna.

- Meadows, D. H., Meadows, D. L., Randers, J., \& Behrens, W. W. (1972). Limits of Growth. New York: New American Library.

- Mathews, J. T. (1989). Redefining Security. Foreign Affairs, 68(2), 162-177. Retrieved from http://www.jstor.org/stable/10.2307/20043906?origin=crossref http://dx.doi.org/10.2307/20043906

- Čr, M. (1995). Standard základního vzdělávání z 22.8, č.j. 20819/95-26. .

- Paris, R. (2001). Human Security: Paradigm Shift or Hot Air. International Security, 26(2), 87-102. Retrieved from http://www.mitpressjournals.org/doi/abs/10.1162/016228801753191141 http://dx.doi.org/10.1162/016228801753191141

- Čr, M. (2013). Rámcový vzdělávací program pro základní vzdèlávání (platný od 1.9. 2013). Praha: MŠMT ČR. Retrieved from http://www.msmt.cz/file/26995

- Sedláček, M. (2006). Ochrana člověka za mimořádných událostí - Osobní bezpečí. Povodně. Učebnice pro 6. ročník základních škol. Praha: Albra s.r.o.

- Sedlacek, M. (2006). Ochrana člověka za mimořádných událostí - Osobní bezpečí. Požáry. Učebnice pro 7. ročník základních škol. Praha: Albra s.r.o.

- Učební plán a učební osnovy pro školy střední (1948, (1948). Učební plán a učební osnovy pro školy střední. Výnos ministerstva školství a osvěty ze dne 31. července 1948; č. A-153 000-II. Praha: Státní nakladatelství.

- Učební osnovy pro 6, (1954). Učební osnovy pro 6. - 10. postupný ročník všeobecně vzdělávacích škol. (1954). Biologie, Výnos ministerstva školství ze dne 25. ledna 1954; č. 4370/54-A-I/1. Praha: Státní pedagogické nakladatelství.

- osnovy, U. (1954). Učební osnovy pro 8. až 11. postupný ročník všeobecně vzdělávacích škol. (1954). Chemie, výnos ministerstva školství ze dne 25. ledna 1954; č. 4370/54-A-I/1. Praha: Státní pedagogické nakladatelství. 
- osnovy, U. (1960). Učební osnovy základní devítileté školy (1960). Fyzika 7.-9. ročník, Schváleno výnosem ministerstva školství a kultury ze dne 8. července 1960; č. 27 723/60-I/1. Praha: Státní pedagogické nakladatelství.

- Školy, o.z.d. (Učební), (1960). Učební osnovy základní devítileté školy. Chemie 8.9. ročník, Schváleno výnosem ministerstva školství a kultury ze dne 8. července 1960; č. 27 723/60-I/1. Praha: Státní pedagogické nakladatelství.

- Školy, U. o. z. d. (1960). Učební osnovy základní devítileté školy. Tělesná výchova 6. -9. ročník, Schváleno výnosem ministerstva školství a kultury ze dne 8. července 1960; č. 27 723/60-I/1. Praha: Státní pedagogické nakladatelství.

- Učební osnovy základní devítileté školy. Občanská výchova 6.-9. ročník, Schváleno výnosem ministerstva školství a kultury ze dne 8. července 1960, \& \& č. 27 723/60-i/1, (1961). Učební osnovy základní devítileté školy. Občanská výchova 6.9. ročník, Schváleno výnosem ministerstva školství a kultury ze dne 8. července 1960; č. 27 723/60-I/1. Praha: Státní pedagogické nakladatelství.

- Školy, U. o. z. d. (1976). Učební osnovy základní devítileté školy. (1976). Branná výchova pro 7. a 8. ročník základní devítileté školy, Schváleno výnosem ministerstva školství ČSR ze dne 5. května 1975; č. 13 270/75-25. Praha: SPN pedagogické nakladatelství.

- Školy, U. o. p. z. (1978). Učební osnovy pro základní školy. Chemie 7.-8. ročník. Chemicko-biologická praktika (Povinně volitelný a nepovinný predmèt). 7.-8. ročník. Fyzikálně chemická praktika (Povinně volitelný a nepovinný předmět). 7.-8. ročník, Schváleno výnosem ministerstva školství ČSR ze dne 13. května 1978; č. 15 759/78-200. Praha: SPN - pedagogické nakladatelství.

- Školy, U. o. z. (1978). Učební osnovy základní školy. Tělesná a sportovní výchova. Sportovní hry 5.-8. ročník, Schváleno výnosem ministerstva školství ČSR ze dne 13. května 1978; č. 15 759/78-200. Praha: SPN - pedagogické nakladatelství.

- Školy, U. o. z. (1978). Učební osnovy základní školy. Občanská nauka 6.-8. ročník, Schváleno výnosem ministerstva školství ČSR ze dne 13. května 1978; č. 15 759/78-200. Praha: SPN - pedagogické nakladatelství.

- 6-8, U. o. z. . F. (1978). Učební osnovy základní školy. Fyzika. 6.-8. ročník. Fyzikálně chemická praktika (Povinně volitelný a nepovinný předmět) 7.-8. ročník. Matematicko-fyzikální praktika (Povinně volitelný a nepovinný předmět) 7.-8. ročník, Schváleno výnosem ministerstva školství ČSR ze dne 13. května 1978; č. 15 759/78-200. Praha: SPN - pedagogické nakladatelství.

- Školy, U. o. z. (1978). Učební osnovy základní školy. Prírodopis 5.-8. ročník. Chemicko-biologická praktika (povinně volitelný a nepovinný předmět 7.-8. ročník), Schváleno výnosem ministerstva školství ČSR ze dne 13. května 1978; č. 15 759/78-200. Praha: SPN - pedagogické nakladatelství.

- Školy, U. o. z. (1987). Učební osnovy základní školy. Fyzika. Fyzikálně chemická praktika. Matematicko-fyzikální praktika pro 6.- 8.r., Schválilo ministerstvo školství ČSR dne 2. prosince 1986; č. 30 250/86-200. Praha: SPN - pedagogické nakladatelství.

- Učební osnovy základní školy. Chemie 7.-8. r. Chemicko-biologická praktika (povinně volitelný a nepovinný předmět 7.-8. r.). Fyzikálně-chemická praktika (povinně a nepovinně volitelný předmět 7.-8. r.), Schválilo ministerstvo školství ČSR dne 2. prosince 1986, , \& č. 30 250/86-200, (1987). . Praha: SPN pedagogické nakladatelství. 
- osnovy, U. (1987). Učební osnovy základní školy. Občanská nauka. 6.-8. ročník, Schválilo ministerstvo školství ČSR dne 15. července 1986; č. 21 557/86-200. Praha: SPN - pedagogické nakladatelství.

- Školy, U. o. z. (1988). Učební osnovy základní školy. Prírodopis 5.- 8.ročník. Chemicko-biologická praktika 7.- 8.ročník, Schválilo ministerstvo školství ČSR dne 15. července 1986; č. 21 557/86-200. Praha: SPN - pedagogické nakladatelství.

- Ullman, R. H. (1983). Redefining Security. International Security, 8(1), 129-153. Retrieved from http://www.jstor.org/stable/2538489?origin=crossref http://dx.doi.org/10.2307/2538489

- škola, V. p. Z. (1996). Vzdělávací program Základní škola. Praha: Fortuna.

- Wced, (1987). Our Common Future. World Commission on Environment and Development. Oxford: Oxford University Press.

- č Zákon, (1953) Zákon č. 31/ 1953 Sb. - Zákon o školské soustavě a vzdělávání učitelů (školský zákon). In Sbírka zákonů republiky Československé, ročník 1953 (pp. 193-196). .

\section{Autoři}

RNDr. Svatava Janoušková, Ph.D.

Centrum pro otázky životního prostředí UK v Praze

Praha

Mgr. Tomáš Kudrna

Lach-Ner,s.r.o. (provozní ředitel)

Neratovice

RNDr. Jan Maršák, CSc.

Nezávislý expert

Praha

PhDr. Václav Pumpr, CSc.

Obchodní akademie Dušní 7

Obchodní akademie Krupkovo náměstí 4

Praha 
Časopis Envigogika vydává Centrum pro otázky životního prostředí UK. Vývoj časopisu je podpořen projektem OP VK Mezioborová sit́ udržitelného rozvoje.

Více najdete na internetových stránkách projektu http://mosur.czp.cuni.cz

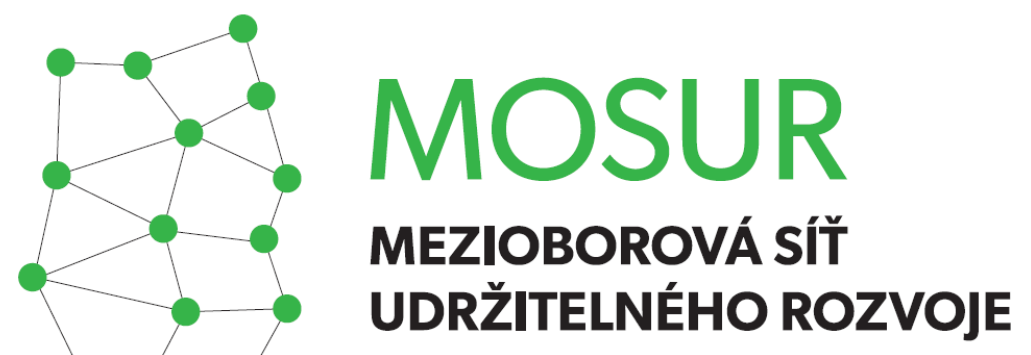

OP VK CZ.1.07/2.4.00/17.0130

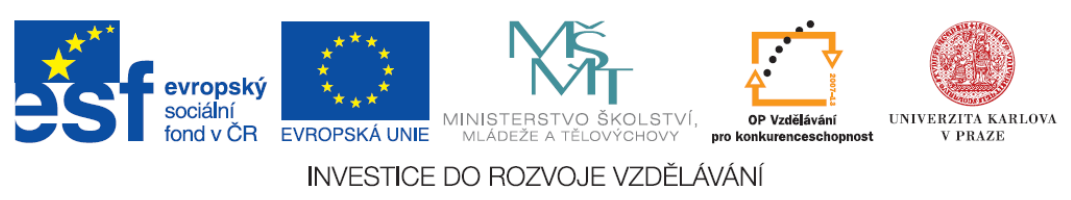

